\title{
Vacuolate-attached filaments: highly productive Ridgeia piscesae epibionts at the Juan de Fuca hydrothermal vents
}

\author{
Karen M. Kalanetra • Douglas C. Nelson
}

Received: 1 July 2009/Accepted: 24 November 2009/Published online: 17 December 2009

(C) The Author(s) 2009. This article is published with open access at Springerlink.com

\begin{abstract}
Vacuolate sulfur bacteria with high morphological similarity to vacuolate-attached filaments previously described from shallow hydrothermal vents (White Point, CA) were found at deep-sea hydrothermal vents. These filamentous bacteria grow in dense mats that cover surfaces and potentially provide a significant source of organic carbon where they occur. Vacuolate-attached filaments were collected near vents at the Clam Bed site of the Endeavour Segment of the Juan de Fuca Ridge and from the sediment surface at Escanaba Trough on the Gorda Ridge. A phylogenetic analysis comparing their 16S rRNA gene sequences to those collected from the shallow White Point site showed that all vacuolate-attached filament sequences form a monophyletic group within the vacuolate sulfur-oxidizing bacteria clade in the gamma proteobacteria. Abundance of the attached filaments was quantified over the length of the exterior surface of the tubes of Ridgeia piscesae worms collected from the Clam Bed site at Juan de Fuca yielding a per worm average of $0.070 \pm 0.018 \mathrm{~cm}^{3}(n=4)$. In agreement with previous results for White Point filaments, anion measurements by
\end{abstract}

Communicated by M. Kühl.

K. M. Kalanetra · D. C. Nelson

Department of Microbiology, University of California,

357 Briggs Hall, Davis, CA 95616, USA

Present Address:

K. M. Kalanetra $(\square)$

Department of Public Health Sciences,

University of California, One Shields Avenue,

Davis, CA 95616, USA

e-mail:kmkalanetra@ucdavis.edu ion chromatography showed no detectable internal nitrate concentrations above ambient seawater $(n=9)$. For one $R$. piscesae tube worm "bush" at the Easter Island vent site, potential gross epibiont productivity is estimated to be 15 to $45 \times$ the net productivity of the worms.

\section{Introduction}

The morphological and physiological diversity detected within the vacuolate sulfur bacteria (VSB) as defined morphologically and phylogenetically has continued to expand. Discoveries of Thiomargarita spp. and the vacuolate-attached filaments (VAF) from White Point, California and Cape Palinuro, Italy (Mattison et al. 1998; Schulz et al. 1999; Kalanetra et al. 2004, Kalanetra et al. 2005) have added substantially to our understanding of this phylogenetically compact group within the gamma proteobacteria. The vacuolate sulfur bacteria typically occur in dense populations in environments that span a gradient between a high flux of sulfide (their electron donor) and of their electron acceptor (nitrate or oxygen), which they typically acquire from the overlying seawater. These environments include cold seeps, hydrothermal vents and springs, and areas of coastal upwelling (Maier and Gallardo 1984; Jannasch et al. 1989; Fossing et al. 1995; McHatton et al. 1996; Jørgensen and Gallardo 1999; Otte et al. 1999; Schulz et al. 1999; Nikolaus et al. 2003). Additionally, it is clear that the presence of VSB in more typical eutrophic marine sediments has been underestimated until recently $(\mathrm{Mu} \beta \mathrm{mann}$ et al. 2003; Sayama 2001). Until very recently (Kalanetra et al. 2004), all vacuolate sulfur bacteria investigated were found to accumulate nitrate internally, often to concentrations 1,000 times or more above that of ambient seawater. It is 
assumed-but not absolutely proven-that their large central vacuoles aid in storage of nitrate, which they can use as a terminal electron acceptor presumably while oxidizing sulfide to sulfate. Thiomargarita namibiensis and some vacuolate Beggiatoa spp. have been shown to be capable of using oxygen as well as, and possibly in preference to, nitrate (McHatton 1998; Schulz and de Beer 2002). Oxygen is likely to be the preferred electron acceptor for the White Point vacuolate-attached filaments (Kalanetra et al. 2004) since they do not accumulate nitrate from the surrounding environment.

At hydrothermal vents, areas favoring low temperature sulfide oxidation (e.g. diffuse flow of low temperature hydrothermal fluids) have been determined, through thermodynamic calculations, to be those providing the most potential metabolic energy for support of micro- and macroorganisms (McCollom and Shock 1997). Deep-sea hydrothermal vents support unique communities of organisms that rely on chemosynthetic bacteria for primary production. In most ecosystems, the ultimate source of energy for carbon fixation is light, but in chemosynthetic vent communities, the majority of primary production is driven by oxidation of reduced sulfur compounds (Jannasch 1985; Van Dover 2000). At these locations, many macro-organisms (e.g. tubeworms, clams, mussels) rely on endosymbiotic, chemoautotrophic, sulfide-oxidizing microorganisms for survival (Van Dover and Fry 1994; Van Dover 2000). Mats of chemoautotrophic sulfur-oxidizing bacteria (e.g. Beggiatoa spp., epibionts of Rimicaris exoculata) may also provide a food source for macrofauna not reliant on symbioses and a source of organic carbon for heterotrophic bacteria (Van Dover and Fry 1994; Polz et al. 1998; Colaço et al. 2002.). Carbon isotope data from the Gorda Ridge and Juan de Fuca Ridge suggest that organic carbon fixed by free-living (non-endosymbiotic) chemoautotrophic bacteria may be more important to upper trophic levels than endosymbiotic production at these specific vents (Van Dover and Fry 1994). Whether carbon is fixed by non-endosymbiotic chemoautotrophs at a rate greater than by endosymbionts or is simply more readily available to consumers are open questions for these vents.

Dense mats of attached filaments resembling VAF from White Point (Kalanetra et al. 2004) were found at deep-sea hydrothermal vents at the Endeavour segment of the Juan de Fuca Ridge and at Escanaba Trough along the Gorda Ridge. An investigation was carried out to determine the evolutionary and physiological similarities of these populations to VAF from the shallow White Point vents (Kalanetra et al. 2004). Estimates were also made of the abundance and potential contribution to primary production of VAF mats living on tubeworms at Juan de Fuca vents.

\section{Materials and methods}

Sample collection

Samples of vacuolate-attached filaments (VAF) were collected on two research expeditions: (1) from August through September, 1999 (R/V Atlantis) from the Clam Bed hydrothermal vents $\left(47^{\circ} 57.73^{\prime} \mathrm{N}, 129^{\circ} 05.55^{\prime} \mathrm{W}\right)$ at the Endeavour Segment of the Juan de Fuca Ridge (depth ca. 2,200 m) using the submersible Alvin (dives 3459 and 3462); (2) in July of 2002 (R/V Western Flyer) from Escanaba Trough on the Gorda Ridge (depth ca. 3,200 m; $41^{\circ} 00.083^{\prime} \mathrm{N}, 127^{\circ} 29.640^{\prime} \mathrm{W}$; dive $\mathrm{T}-452$ ) using the remotely operated vehicle Tiburon.

At the Clam bed hydrothermal vent site, individual Ridgeia piscesae tubeworms covered with filamentous bacteria were collected as previously described (Urcuyo et al. 2003) using the research submersible Alvin. On the ship, the tubeworms were kept submerged in natural seawater $\left(4^{\circ} \mathrm{C}\right)$, and processed within $24 \mathrm{~h}$. Two types of vacuolate-attached filament (VAF) collections were made from the tubeworms. The first type was used for enzyme assays, DNA extraction, and determination of biovolume, protein and anion concentration (per cell). Here, bacterial filaments were suctioned with a Pasteur pipette (or scraped with a scalpel) from outer tube surfaces of $R$. piscesae and rinsed with sterile natural seawater. A similar suspension was made of filaments collected by scraping with a scalpel from the surface of a thermistor array (Urcuyo et al. 2003) that had been deployed for approximately 1 year at Clam Bed. Each individual suspension was processed as follows: debris was allowed to settle out of the mix $(\sim 10 \mathrm{~min})$. Filaments were then rinsed with sterile natural seawater and transferred to generate a homogenous suspension of known volume. Aliquots (1-3.6 ml) were transferred for DNA extraction, anion concentration measurement, protein determinations and enzyme analysis, from this suspension to microcentrifuge tubes. These were then pelleted by centrifugation $(8,000 \times g$ for $5-10 \mathrm{~min})$ and stored at $-80^{\circ} \mathrm{C}$ until processing. Supernatants were transferred to clean microcentrifuge tubes and stored at $-80^{\circ} \mathrm{C}$. Other aliquots $(1 \mathrm{ml})$ from each suspension were preserved in glutaraldehyde (final concentration $1.5-2.3 \%$ ) or formalin (final concentration 1.7\%) and stored at $4^{\circ} \mathrm{C}$ for phase contrast or fluorescence microscopy. Juan de Fuca VAF preserved in formalin were stained with fluorescein isothiocyanate (FITC; Sigma) as previously described (Kalanetra et al. 2004), and images were recorded with a Leica TCS-SP laser-scanning confocal microscope.

The second type of VAF collection made from the $R$. piscesae tubeworms was used to estimate VAF biomass and distribution on individual $R$. piscesae tubeworms. 
A total of four individual $R$. piscesae were randomly selected from two different dives (two each) (Clam Bed site-dive 3459 and 3462). VAF were scraped off, using a scalpel, from the exterior surface of the $R$. piscesae tubeworms along the full length of each tube. Beginning at the anterior of the tubeworms every second $5-\mathrm{cm}$ length was sampled completely around the tube circumference. Filaments were rinsed with seawater and preserved in glutaraldehyde (final concentration $2 \%$ ) or formalin (final concentration $1.7 \%)$.

Control samples of seawater were collected using a Niskin bottle from: (1) immediately above a $R$. piscesae tubeworm bush (Clam Bed site) where worm tubes were covered with VAF; (2) immediately above an $R$. piscesae tubeworm bush (Easter Island site) where worm tubes lacked VAF; (3) at a control site away from known vents.

At Escanaba Trough, filaments were collected from a sediment-covered area of seafloor by suction and transferred to a known volume of sterile natural seawater. Aliquots for DNA extraction were transferred to microcentrifuge tubes, pelleted by centrifugation, and stored at $-20^{\circ} \mathrm{C}$

White Point VAF samples were collected in 2002 as previously described (Kalanetra et al. 2004). Cell pellets were stored at $-80^{\circ} \mathrm{C}$ and processed for ribulose bisphosphate carboxylase-oxygenase ( $\mathrm{RuBisCO}$ ) enzyme activity as described in the next paragraph.

16S rRNA sequence and phylogenetic analysis

Chromosomal DNA was extracted from frozen cell pellets from Juan de Fuca and Escanaba Trough using a guanidine thiocyanate method (Pitcher et al. 1989). The 16S rRNA gene was amplified in three parts from mixed template DNA using the following primer sets: (1) general eubacterial primers $341 \mathrm{f}$ and 534r (5'-CCTACGGGAGGCAGC AG-3' and 5'-ATTACCGCGGCTGCTGG-3', respectively; corresponding to $341-357 \mathrm{bp}$ and $534-518 \mathrm{bp}$, Escherichia coli numbering; Muyzer et al. 1993); (2) general eubacterial primer $8 \mathrm{fpl}$ and VAF-specific primer WPF464r (5'-AGAGTTTGATCCTGGCTCAG-3' and 5'-AGCTTTAAGTTTTTCTTCCC-3', respectively; corresponding to 8-27 bp and 464-445 bp; Weisburg et al. 1991; Kalanetra et al. 2004); (3) VAF-specific primer WPF445f and general eubacterial primer 1492rpl (5'-GG GAAGAAAAACTTAAAGCT-3' and 5'-GGTTACC TTGTTACGACTT-3', respectively; corresponding to 445-464 bp and 1492-1510 bp; Weisburg et al. 1991; Kalanetra et al. 2004). Amplification, cloning, and sequencing were carried out as previously described (Kalanetra et al. 2004).

The Juan de Fuca and Escanaba Trough VAF 16S rRNA gene sequences were derived from the combination of three bi-directional sequences. These sequences were manually aligned with sequences of other sulfur-oxidizing gammaand epsilon-proteobacteria using manual alignment procedures and phylogenetic analyses as previously described (Kalanetra et al. 2004). Briefly, sequences were manually aligned using MacClade Version 4.05 (Maddison and Maddison 2002). A small mask phylogenetic analysis using an alignment of 16S rRNA gene base pairs 126-1376 (Escherichia coli numbering) was carried out. PAUP* 4.0 (Swofford 2000) was used to infer a minimum evolutionary tree using the Kimura two-parameter model and checked with 1,000 bootstrap replicates.

Nucleotide sequence accession numbers

The 16S rRNA gene sequences of the Juan de Fuca VAF and the Escanaba Trough VAF bacteria have been deposited in the GenBank database under accession numbers AY883933 and AY883934, respectively.

Protein to biovolume ratio, width distribution, and anion concentrations

Biovolume and filament diameter distribution were determined on glutaraldehyde-preserved samples of Juan de Fuca VAF suspensions (Clam Bed site) as previously described (Nelson et al. 1986; Nelson et al. 1989). Corresponding protein determinations were made using the Coomassie brilliant blue dye-binding technique (Bradford 1976) with previously described modifications (McHatton et al. 1996; Nelson et al. 1989).

Filament diameter distribution and biovolume were determined for glutaraldehyde-and formalin-preserved Juan de Fuca VAF samples collected for quantitative estimates of total biovolume on four individual $R$. piscesae tubes. Using phase contrast microscopy, width class determinations were made by measuring the diameters of the first 50-65 filaments encountered per $5 \mathrm{~cm}$ increment of one worm tube (315 filaments measured). Width classes were assigned according to apparent clusters of filament diameters (see Fig. 4). Total VAF biovolume was determined on acridine orange stained aliquots (1-3 ml) as previously described (Nelson et al. 1989) using the width class designations.

Intracellular anion concentrations of the Juan de Fuca VAF were determined by ion chromatography using cell pellet lysates as previously described (Kalanetra et al. 2004).

RuBisCO enzyme activity measurements

White Point and Juan de Fuca VAF frozen cell pellets were thawed on ice and resuspended in assay buffer $(100 \mathrm{mM}$ 
Tris hydrochloride, $20 \mathrm{mM} \mathrm{MgCl}_{2}, 5 \mathrm{mM} \mathrm{NaHCO}$, $6.5 \mathrm{mM}$ dithiothreitol; $\mathrm{pH}$ 8.2). Chilled cells were lysed by sonication (several brief pulses, at the minimum setting) with a Model 1000L sonicator (Ultrasonic Power Corporation) and centrifuged $\left(16,100 \times g, 10 \mathrm{~min}, 4^{\circ} \mathrm{C}\right)$ to clarify the lysate. The extract was assayed for ribulose bisphosphate carboxylase-oxygenase (RuBisCO) at $30^{\circ} \mathrm{C}$ as previously described (Nelson and Jannasch 1983).

\section{Statistics}

Mean values are presented \pm one standard error (standard deviation of the mean) unless stated otherwise.

\section{Results}

VAF morphology and widespread occurrence

In 1999 at the Clam Bed site of the Juan de Fuca vents, VAF formed dense macroscopically visible mats that covered a variety of biotic and abiotic surfaces adjacent to diffuse hydrothermal flow. VAF were observed to cover the entire plastic frame of a thermistor array that was retrieved from the Clam Bed site as well as the exterior of scale worms, rocks, and tubes of Ridgeia piscesae tubeworms that formed tightly packed "bushes" (Urcuyo et al. 2003). The Escanaba Trough filaments collected in 2002 were attached directly to the sediment surface in a thick mat (Fig. 1). At both locations (Juan de Fuca and Escanaba Trough), the terminal cell at the slightly wider basal end of each filament was attached, while the opposite end of the filament extended one to several $\mathrm{cm}$ into the seawater from the point of attachment.

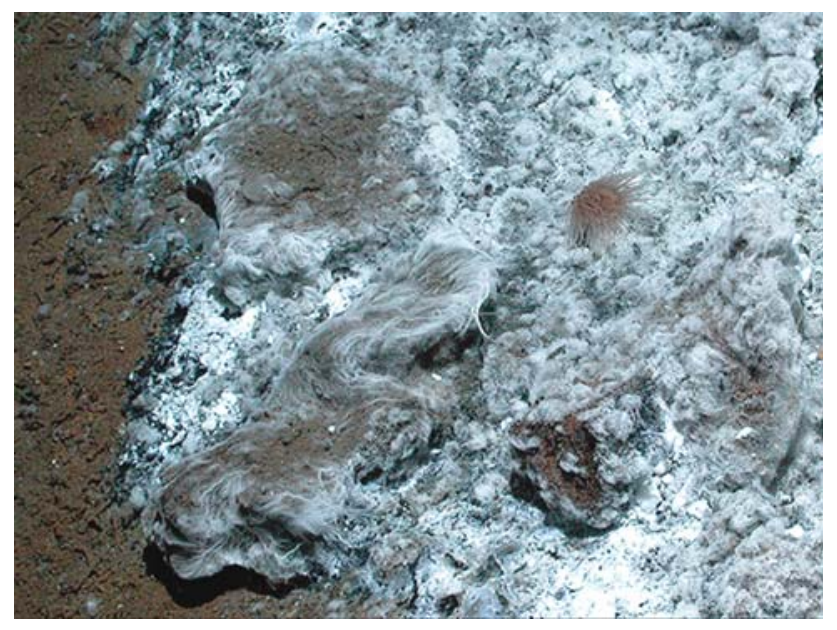

Fig. 1 Photo of vacuolate-attached filaments (VAF) on the sediment surface at Escanaba Trough. Photo courtesy of Monterey Bay Aquarium Research Institute
Cells from Juan de Fuca were shown by microscopic visualization of FITC-stained cells (Fig. 2) to have a thin layer of cytoplasm surrounding a large central vacuole. Cells with crosswalls, presumably in the middle of celldivision, were also observed (Fig. 2). Filaments observed by light microscopy were visualized to have sulfur globules in the cytoplasmic layer, similar to those reported from the White Point VAF (Kalanetra et al. 2004).

Phylogenetic analysis

A single 16S rRNA gene was assembled from sequences amplified from mixed genomic DNA extracted from the Juan de Fuca VAF-dominated collection. Another was assembled from Escanaba Trough VAF-dominated material. For each, this was accomplished in three parts using general eubacterial and VAF-specific primers from DNA extracted from frozen cell pellets. For both vent VAF populations, a short fragment ( $\sim 200 \mathrm{bp}$ ) was first amplified with universal eubacterial primers $341 \mathrm{f}$ and 534r. These fragments were cloned and 10 (Escanaba Trough) or 19 (Juan de Fuca) clones were randomly selected for sequencing. Sequences were screened by BLAST searches against the nucleotide database at the National Center for Biotechnology Information's website at http://www.ncbi. nlm.nih.gov/. For Escanaba Trough and Juan de Fuca VAF sequences one and five clones, respectively, were found that were almost identical ( $1 \mathrm{bp}$ difference) to the White Point VAF sequence (Kalanetra et al. 2004). Forward and reverse VAF-specific primers (WPF445f and WPF464r; Kalanetra et al. 2004) linked specifically to the White Point sequence by FISH (Kalanetra et al. 2004) were used in

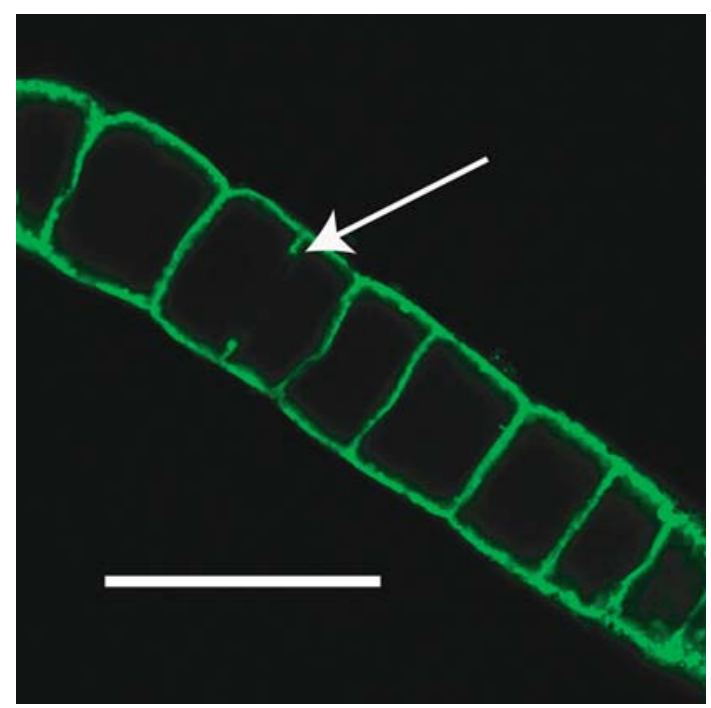

Fig. 2 Confocal image of a Juan de Fuca filament stained with FITC showing the large internal vacuoles; Bar, $100 \mu \mathrm{m}$. Arrow indicates partial cross-wall in longest cell, which is presumed to be in the process of dividing 
conjunction with general eubacterial primers (8fpl and 1492rpl; Weisburg et al. 1991) to amplify almost the entire $16 \mathrm{~S}$ rRNA gene for each population. Amplified fragments were cloned and clones were randomly selected for sequencing. For primer pair 8fpl and WPF464r, 2 sequences of 7 (Escanaba Trough) and 4 of 12 (Juan de Fuca) were identical and were used to assemble the single composite sequence from each site. For primer pair WPF445f and 1464rpl, 7 bidirectional, overlapping sequences out of 10 (Escanaba Trough) and 4 of 4 (Juan de Fuca) were the same, and were again used in assembly of the single composite from each site. The resulting $16 \mathrm{~S}$ rRNA gene sequences are $99 \%$ similar to and have 9 (Escanaba Trough) or 11 (Juan de Fuca) base pair differences out of 1,464 possible from the White Point VAF sequence.
The Juan de Fuca and Escanaba Trough VAF sequences were found by phylogenetic analysis to form a closely related cluster within the larger vacuolate sulfur-oxidizer clade (Fig. 3). The bootstrap value for this branch is $100 \%$ based on minimum evolutionary analysis and 1,000 bootstrap replicates.

Biovolume, width, and protein determinations

Individual chains of cells of the Juan de Fuca VAF ranged from 9 to $96 \mu \mathrm{m}$ in filament diameter (Fig. 4). From all four tube worms VAF: (1) between 9 and $30 \mu \mathrm{m}$ diameter (average diameter $=22 \mu \mathrm{m} ; n=873$ ) (Fig. 5, black bars) made up $80.9 \%$ of the filaments measured and $64.8 \%$ of the total biovolume; (2) between 30 and $53 \mu \mathrm{m}$ diameter (average diameter $=38 \mu \mathrm{m} ; n=85)($ Fig. 5 , gray bars)
Fig. 3 Minimum evolutionary tree of the sulfur-oxidizing gamma proteobacteria, including VAF from White Point, Juan de Fuca, and Escanaba Trough. Tree is based on a $16 \mathrm{~S}$ rRNA gene sequence alignment of positions 1261376 (E. coli numbering). Epsilon proteobacteria are included as the outgroup. Numbers represent bootstrap values greater than $50 \%(1,000$ replicates). Accession numbers are shown. Box A: nonvacuolate Beggiatoa and Thioploca spp.; Box B: vacuolate, nitrate-accumulating Beggiatoa and Thioploca spp.; Box $C$ : Box $B$ plus VAF

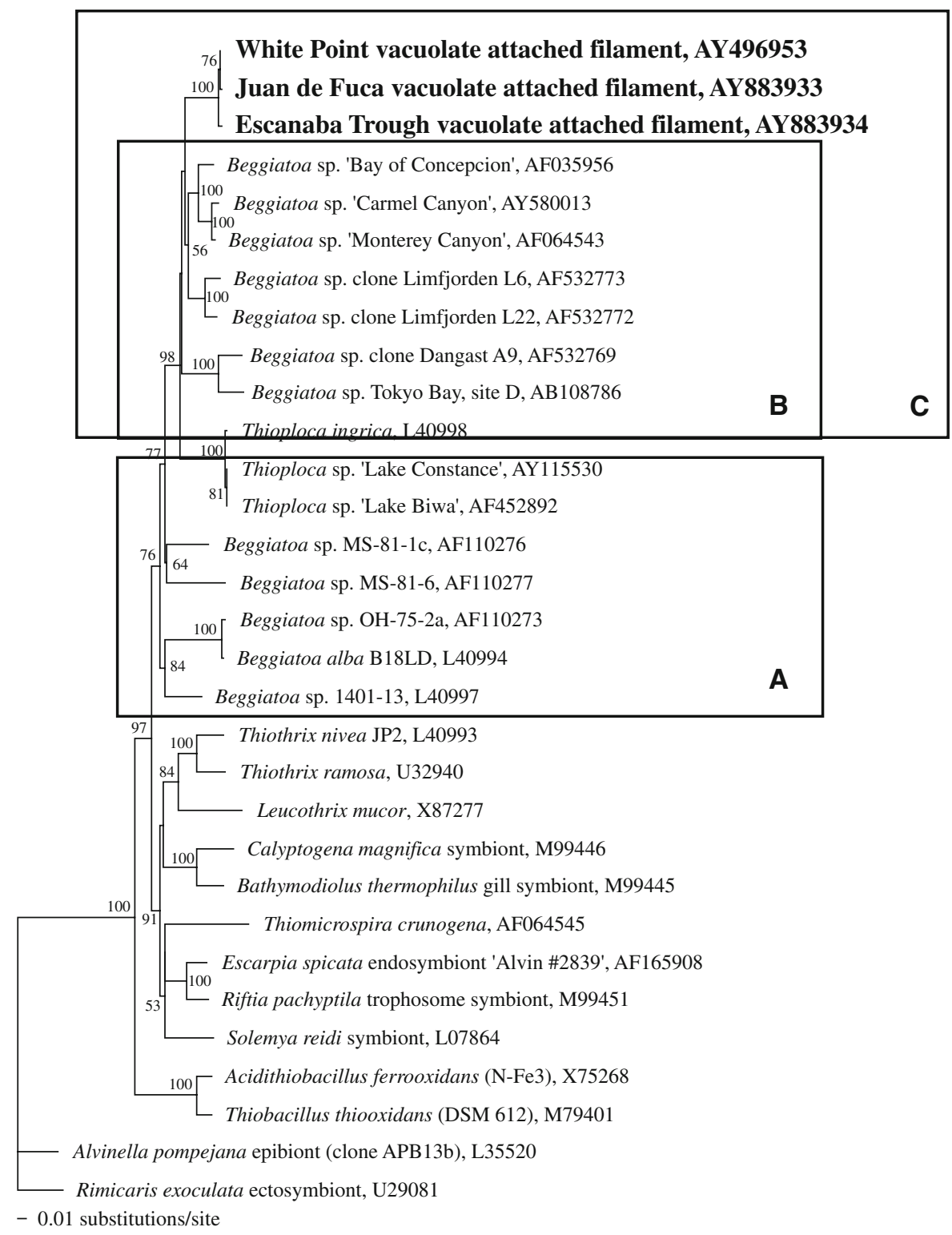


Fig. 4 Filament frequency vs. filament diameter for VAF collected from a single $R$. piscesae tubeworm at hydrothermal vents (Clam Bed site) on the Juan de Fuca Ridge

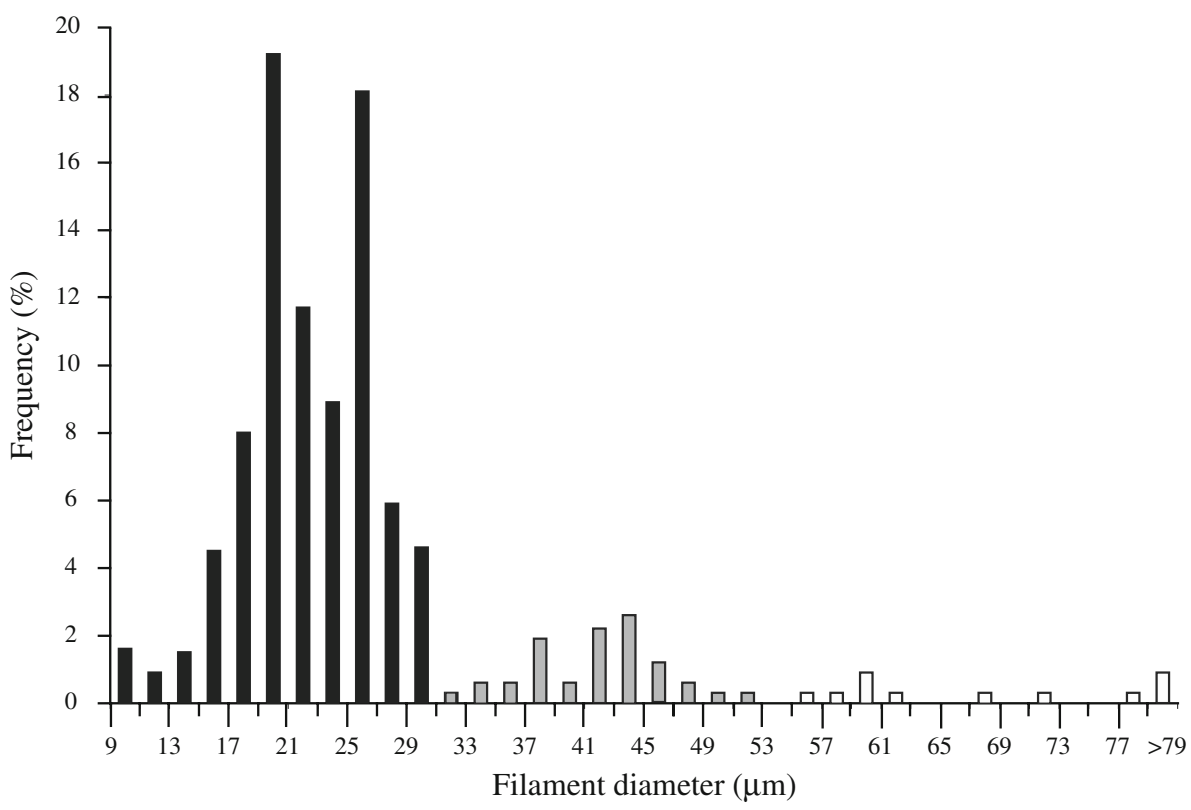

made up $15.2 \%$ of the filaments measured and $31.6 \%$ of the total biovolume; (3) VAF greater than $53 \mu \mathrm{m}$ diameter (average diameter $=70 \mu \mathrm{m} ; n=13$ ) (Fig. 5, white bars) made up $3.8 \%$ of the filaments counted and $3.5 \%$ of the total biovolume. Unicells and non-vacuolate filaments were not counted.

VAF biovolume was calculated based on the three width classes described above over the length of four $R$. piscesae tubeworms (Fig. 5) ranging in length from 85 to $132 \mathrm{~cm}$ and having outer tube diameters (anterior end) of 5.8-7.6 mm. The majority of the VAF covered the anterior (open) end of the worm tubes and declined in filament density toward the posterior root end. The average biovolume of filaments attached to the outermost $50 \mathrm{~cm}$ of a tube was $0.067 \pm 0.018 \mathrm{~cm}^{3}(n=4)$, which is $96 \%$ of the total average biovolume of VAF measured $\left(0.070 \pm 0.018 \mathrm{~cm}^{3}\right.$; $n=4$ ). The protein to biovolume ratio of Juan de Fuca VAF was calculated to be $13.4 \pm 1.5 \mathrm{mg}$ protein $\mathrm{cm}^{-3} \mathrm{ml}^{-1}$.

Internal anion measurements

Anion concentrations of cell lysates of VAF collected from Juan de Fuca (1999) were analyzed by ion chromatography. All lysates showed no detectable nitrate beyond the concentration of ambient seawater $(n=9)$. By contrast, phosphate $\left(\mathrm{PO}_{4}{ }^{3-}\right)$ was detected in all samples measured. Using corresponding protein measurements, these data yielded $18.8 \pm 3.34 \mathrm{mM} \mathrm{PO}_{4}{ }^{3-}(n=9)$ when calculated as the cytoplasmic concentration, i.e. assumed to be absent from the vacuole but present in the cytoplasm.

Nitrate concentrations measured for seawater samples were: (1) $12.54 \pm 0.32 \mu \mathrm{M}$ over $R$. piscesae bush where tubes were covered with VAF (Clam Bed site, Juan de
Fuca); (2) $10.81 \pm 0.81 \mu \mathrm{M}$ over a remote site (Juan de Fuca); (3) $9.7 \pm 1.92 \mu \mathrm{M}$ over $R$. piscesae tubeworm bush without VAF (Easter Island site, Juan de Fuca).

RuBisCO enzyme activity measurement

RuBisCO activity of White Point VAF cell lysates measured at $30^{\circ} \mathrm{C}$, averaged $2.48 \pm 1.76 \mathrm{nmol} \mathrm{CO}_{2}$ fixed $\min ^{-1} \mathrm{mg}^{-1}$ protein $(n=2)$. No RuBisCO activity could be detected in a 5-year-old frozen sample of VAF from Juan de Fuca that had been compromised by previous thawing and refreezing.

\section{Discussion}

Mats of attached filamentous sulfur bacteria superficially similar to those described in this study have also been reported from shallow hydrothermal vents at White Point, California (Stein 1984; Jacq et al. 1989; Kalanetra et al. 2004), East Pacific Rise (Gaill et al. 1987), shallow vents off of Kolbeinsey, Iceland (Fricke et al. 1989), and in submarine caves with hydrothermal springs at Cape Palinuro, Italy (Mattison et al. 1998). Electron micrographs of VAF from the Italian caves clearly showed large membrane-bound vacuoles that encompass roughly $75 \%$ of the cell volume (Mattison et al. 1998). Cells of VAF from White Point (Kalanetra et al. 2004) and Juan de Fuca (this study) have been shown by microscopic visualization of FITC-stained cells (Fig. 2) and by calculations of protein: biovolume ratios $(7.6 \pm 0.8$ and $13.4 \pm 1.5 \mathrm{mg}$ protein $\mathrm{cm}^{-3} \mathrm{ml}^{-1}$, respectively; Table 1) to contain large internal vacuoles. When these protein:biovolume ratios are 

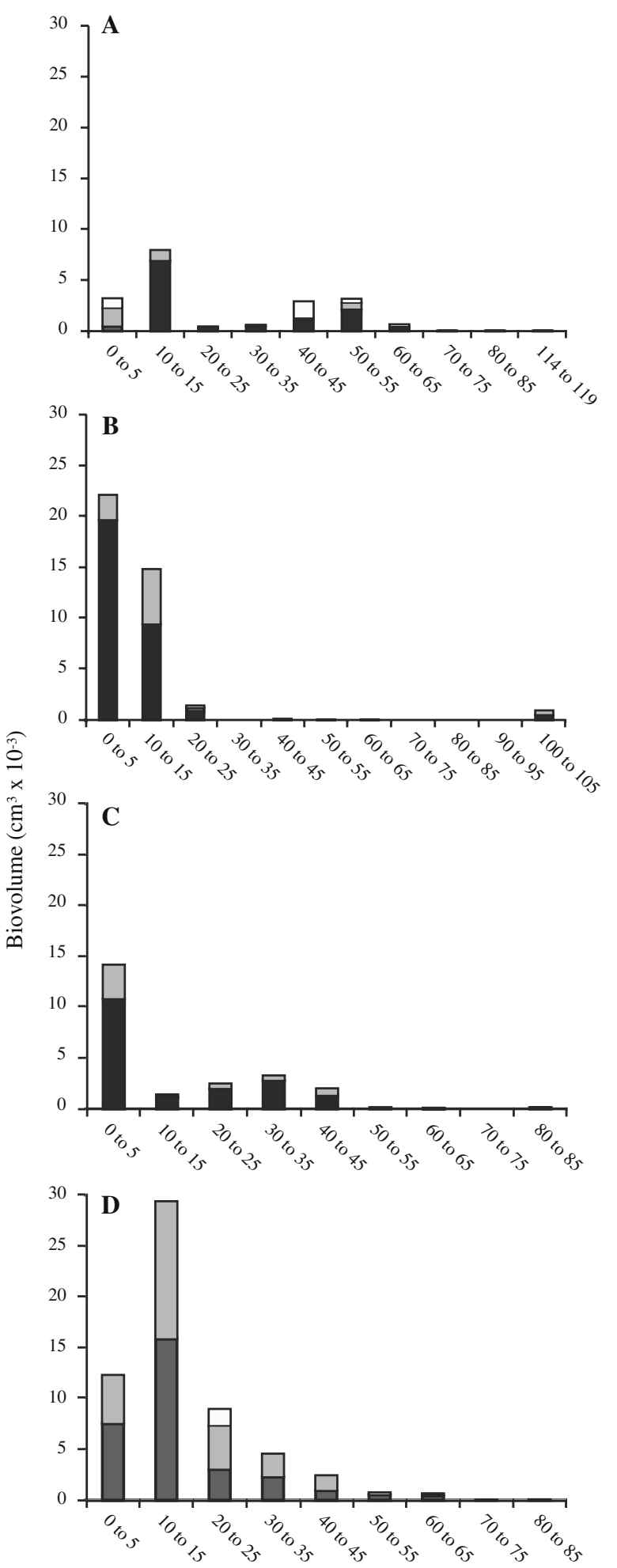

Location along length of tubeworm $(\mathrm{cm})$

Fig. 5 VAF biovolume $\left(\mathrm{cm}^{3}\right)$ vs. location along the length of the tube of individual $R$. piscesae specimens collected from Juan de Fuca (Clam Bed site) on dives 3459 (a and b) and 3462 (c and d). The anterior (open) end of each tube is designated as " $0 \mathrm{~cm}$ ". Black, gray, and white bars represent VAF with filament diameters between 9 and $30 \mu \mathrm{m}($ avg. $=22 \mu \mathrm{m}), 30$ and $53 \mu \mathrm{m}($ avg. $=38 \mu \mathrm{m})$, and $>53 \mu \mathrm{m}$ (avg. $=70 \mu \mathrm{m}$ ), respectively compared to a non-vacuolate control Beggiatoa sp. $\left(121 \pm 17 \mathrm{mg}\right.$ prot $\mathrm{cm}^{-3}$; Kalanetra et al. 2004), it is estimated that vacuoles comprise $89 \%$ of VAF from Juan de Fuca (Table 1), quite close to the value of $94 \%$ calculated earlier (Kalanetra et al. 2004) for VAF from White Point.

Juan de Fuca VAF cytoplasmic phosphate concentrations $\left(18.8 \pm 3.34 \mathrm{mM} \mathrm{PO}_{4}{ }^{3-}\right)$ were similar to those measured for Escherichia coli and White Point VAF $\left(18.2 \pm 0.09\right.$ and $33.6 \pm 10.3 \mathrm{mM} \mathrm{PO}_{4}{ }^{3-}$, respectively) (Kalanetra et al. 2004). This typical cytoplasmic level of phosphate argues that cell membranes were, in general, not compromised in collected VAF. Hence, failure to detect an internal nitrate signal in these collections cannot be attributed to extensive lysis during washing and centrifugation steps, but rather represents a presumptive intracellular concentration, i.e. an average of cytoplasmic and vacuolar nitrate, that is below the detection limit $(800 \mu \mathrm{M})$.

The presence of comparable concentrations of nitrate in seawater over the tubeworm bushes that did and did not display VAF and at the remote non-vent site argues against nitrate limitations. Because these concentrations are in the same range as those tabulated for environments surrounding a wide variety of vacuolate sulfur bacteria that do accumulate nitrate (Jørgensen and Nelson 2004), low levels of ambient nitrate do not appear to be an explanation for the absence of nitrate in these VAF.

While it does not appear that the vacuoles in VAF serve the purpose of nitrate storage for respiration as they do in all other VSB tested to date, it is possible that they could aid in the transient storage of oxygen for the same purpose. There is ample precedent within the vacuolate sulfur bacteria for respiration based on oxygen. The very large vacuolate sulfur bacterium, Thiomargarita namibiensis, has been shown to oxidize sulfide at a higher rate under oxic conditions than under anoxic conditions (Schulz and de Beer 2002). Additionally, the vacuolate marine Beggiatoa sp. from Monterey Canyon has been shown to consume oxygen at rates ranging from 8 to $25 \mathrm{nmol} \mathrm{O}_{2} \mathrm{~min}^{-1} \mathrm{mg}_{\text {protein }}{ }^{-1}$ (McHatton 1998), which is considerably greater than its average rate of nitrate consumption (Table 1). The ability to concentrate and store nitrate enables other vacuolate sulfur bacteria (e.g. Thiomargarita sp., Beggiatoa spp., and Thioploca spp.) to survive long periods of anoxia (Table 1). In part, this capacity for long anoxic survival with sustained metabolic activity is due to the above-discussed reduced rate of respiration with nitrate versus that with oxygen. In the main, however, this capacity stems from the ability of these bacteria to accumulate a charged ion (nitrate) to very high internal concentrations due to the properties of biological membranes. By contrast, because $\mathrm{O}_{2}$ should be freely permeable across membranes, it is assumed that vacuolar oxygen concentrations cannot exceed air 
Table 1 Respiration rates and anoxic survival potential for representatives of the vacuolate sulfur bacteria

\begin{tabular}{|c|c|c|c|c|}
\hline Bacterium & $\begin{array}{l}\mathrm{NO}_{3}^{-} \text {stored?: } \\
\text { (molarity) } \\
\text { respiration rate }\left(\mathrm{nmol} \mathrm{NO}_{3}^{-} \mathrm{min}^{-1}\right. \\
\quad \mathrm{mg}^{-1} \text { protein) }\end{array}$ & $\begin{array}{l}\text { Anoxic survival } \\
\text { on stored } \mathrm{NO}_{3}^{-}\end{array}$ & Respire $\mathrm{O}_{2}$ ? & $\begin{array}{l}\text { Cell diameter } \\
(\mu \mathrm{m}) ; \% \text { vacuole }\end{array}$ \\
\hline Thiomargarita namibiensis $^{\mathrm{a}}$ & $\begin{array}{l}\text { Yes }(0.1-0.8 \mathrm{M}) \\
\sim 1\end{array}$ & 15-120 days & Yes & $\begin{array}{l}100-750 \\
98 \%\end{array}$ \\
\hline Thioploca araucae \& Thioploca chileae $\mathrm{b}^{\mathrm{b}}$ & $\begin{array}{l}\text { Yes }(0.16-0.5 \mathrm{M}) \\
\sim 1\end{array}$ & $8-25$ days & No & $\begin{array}{l}12-42 \\
90 \%\end{array}$ \\
\hline Beggiatoa sp. 'Monterey Canyon'c & $\begin{array}{l}\text { Yes }(0.16 \mathrm{M}) \text {; } \\
1-4\end{array}$ & $1-4$ days & Yes & $\begin{array}{l}65-85 \\
80 \%\end{array}$ \\
\hline Vacuolate-Attached Filaments (VAF) & $\mathrm{No}^{\mathrm{d}}$ & $\begin{array}{l}\text { Not on } \mathrm{NO}_{3}^{-} \\
1-16 \min \mathrm{O}_{2}^{\mathrm{e}}\end{array}$ & $\begin{array}{l}\text { Assumed }^{\mathrm{f}} \text {, } \\
\text { Not tested }\end{array}$ & $\begin{array}{l}10-112^{\mathrm{d}} \\
89-94 \%\end{array}$ \\
\hline
\end{tabular}

Major finding of the study and a key difference between VAF and other vacuolate sulfur-oxidizers is indicated in bold

a Schulz et al. 1999; Schulz and de Beer 2002

b Fossing et al. 1995; Otte et al. 1999; data reported collectively for both species

c McHatton 1998; McHatton et al. 1996

${ }^{d}$ Kalanetra et al. 2004; this study

e Calculated over temperature range of $4-25^{\circ} \mathrm{C}$ assuming cytoplasm: vacuole ratio shown in column $5 . \mathrm{O}_{2}$ respiration rate $(8-25 \mathrm{nmol}-$ $\min ^{-1} \mathrm{mg}^{-1}$ protein) estimated based on McHatton (1998). $\mathrm{Q}_{10}$ for respiration taken as 2.0 . Cytoplasm assumed to be $80 \%$ water $+20 \%$ dry matter and protein assumed to comprise $50 \%$ of cellular dry matter. Comparable rate $\left(13 \mathrm{nmol} \mathrm{min} \mathrm{mg}^{-1} \mathrm{mg}^{-1}\right.$ protein) extrapolated for $T$. namibiensis from data of Schulz and de Beer, 2002. Vacuolar $\mathrm{O}_{2}$ concentration assumed at $240 \mu \mathrm{M}$

${ }^{\mathrm{f}}$ Not yet confirmed by respirometry but most logical alternative to nitrate respiration

saturation adjusted for ambient salinity and temperature. If vacuolar salinity is comparable to natural seawater (35\%), maximum vacuolar oxygen concentrations should be in the range of $320 \mu \mathrm{M}\left(4^{\circ} \mathrm{C}\right)$ to $210 \mu \mathrm{M}\left(25^{\circ} \mathrm{C}\right)$. For the lower temperature, while also estimating reduced oxygen consumption rates of VSB at $4^{\circ} \mathrm{C}\left(Q_{10}=2\right)$, vacuolar oxygen could support respiration for a maximum of approximately 16 min (Table 1). VAF from all three hydrothermal vent locations are abundant on surfaces immediately adjacent to locations of diffuse hydrothermal flow. Based on in situ observation of turbulent mixing in the regime of VAF, it is expected that if filaments are subjected to periods of anoxia, these would be brief. Under these conditions, passive storage of oxygen in vacuoles is hypothesized to ensure more continuous access to oxygen, thereby providing a selective advantage over non-vacuolate "classical" Thiothrix-type bacteria. The limiting case of fully aerated seawater at a filament surface along with an initially anoxic vacuole and an aqueous diffusion coefficient results in an influx of oxygen substantially greater, per unit surface area, than estimated respiration rates (Nelson, unpublished). Whether oxygen can diffuse into and out of the vacuoles rapidly enough to result in substantial storage and support of respiration depends on its diffusion coefficients in cytoplasm and cell membranes and on the fraction of time filaments spend in oxic vs. anoxic environments.

Few phylogenetic studies of the VAF have been conducted (Kalanetra et al. 2004). Minimum evolutionary analysis (Fig. 3) comparing 16S rRNA gene sequences of sulfur-oxidizing gamma proteobacteria showed Juan de Fuca and Escanaba Trough VAF sequences form a clade with the single sequence previously obtained from White Point VAF. The White Point sequence was confirmed by FISH carried out under increasing hybridization stringencies to be derived from VAF $\geq 10 \mu \mathrm{m}$ (Kalanetra et al. 2004). Likewise, the two VAF sequences derived from deep-sea vent material were from collections dominated by filaments $\geq 10 \mu \mathrm{m}$. It has not been established whether the Juan de Fuca and Escanaba Trough sequences for VAF hybridize specifically with all or only part of the range of filament widths observed. Additionally, sequence heterogenicity between morphologically similar filaments, as noted by $\mathrm{Mu} \beta$ mann et al. (2007), is a concern. Nonetheless, based on the 3 sequences obtained to date, the VAF form a monophyletic group of vacuolate bacteria that do not accumulate nitrate within the otherwise nitrate-accumulating vacuolate sulfur bacteria group (Fig. 3). As noted previously (Kalanetra et al. 2004), this VAF clade is quite distinct from the clade of non-vacuolate Thiothrix spp. (Fig. 3), which points to vacuoles as the taxonomically more important trait when compared with attached filament morphology.

VAF occur in dense mats at some vent sites and not others. The reasons for this distribution are a matter for speculation. Urcuyo et al. carried out measurements of temperature and sulfide concentrations of diffuse hydrothermal fluid associated with $R$. piscesae tubeworm bushes 
at the Clam Bed and Easter Island vent sites at Juan de Fuca (Urcuyo et al. 2003, Urcuyo et al. 2007). Very low hydrothermal flow was recorded with sulfide detected in $60 \%$ of samples taken at plume level of the tubeworms at Clam Bed where dense growth of filamentous bacteria was observed, but no sulfide was detected in any plume level samples from Easter Island (Urcuyo et al. 2003) where there was no growth of VAF on the tubeworms (Urcuyo et al. 2007). Attachment of the VAF to the anterior end of the worm tubes at Clam Bed would likely put them in contact with low concentrations of sulfide while also giving them brief contact with oxic seawater. In other vent systems, short term monitoring of temperature along with sulfide and oxygen concentrations produced the conclusion that, due to reduced chemicals in vent fluids, oxygen is not present in seawater-vent fluid mixtures if temperatures exceed $8-12^{\circ} \mathrm{C}$ (Johnson et al., 1986; 1988). Applying this criterion to the vent fluid temperature-probe studies by Urcuyo et al. (2007) suggests that the base of tube worm clumps at our study site may frequently experience periods of hypoxia or anoxia with occasional occurrence of these conditions near the plume. This view is consistent with our observation that VAF dominate near the anterior end of $R$. piscesae tubes and the possible role, discussed earlier, of vacuoles as sites of transient oxygen storage.

$\mathrm{CO}_{2}$ fixation rates similar to those reported here for White Point VAF have been measured for vacuolate Beggiatoa sp. populations collected at deep-sea vents (Nelson et al. 1989). From the data of Urcuyo et al. (2003), it can be estimated that an $R$. piscesae tubeworm bush containing 3,300 larger individuals (diameter $>2.5 \mathrm{~mm}$; Easter Island vents) adds 1$3 \mathrm{~g}$ dry weight per year. This increase, based on tubeworm growth, can be compared with epibiont productivity. This calculation assumes that VAF from the deep-sea vents can fix $\mathrm{CO}_{2}$ at a rate reflecting the RuBisCO activity of White Point VAF. This assumption seems reasonable since the whole-cell carbon fixation rate or doubling time for symbiotic or free-living sulfur bacteria, respectively, matched the corresponding RuBisCO data closely (Nelson and Jannasch 1983; Nelson et al. 1986, 1995). The calculation also assumes that the biovolume of VAF on this entire tubeworm bush $\left(233 \mathrm{~cm}^{3}\right)$ is accurately reflected by extrapolation of our data. Projecting VAF-derived RuBisCO activity on an entire bush, and taking account of the estimate that only $11 \%$ of this volume is cytoplasm, yields a gross epibiont productivity on this same bush of $45 \mathrm{~g}$ dry matter per year. Based on these calculations, VAF could be an important source of organic carbon at the deep-sea hydrothermal vents where they occur in abundance.

Acknowledgments This research was supported by funds from the U.S. National Science Foundation (NSF-9983119 and NSF-0526653) and the Department of Energy (DE-FG03-OOER15077). We are grateful to Chuck Fisher, Robert Zierenberg, Ellen Avery, the crews of the Atlantis and the Western Flyer, and the pilots of the submersible Alvin for their assistance in sample collection. The experiments carried out in this study comply with the laws of the United States.

Open Access This article is distributed under the terms of the Creative Commons Attribution Noncommercial License which permits any noncommercial use, distribution, and reproduction in any medium, provided the original author(s) and source are credited.

\section{References}

Bradford MM (1976) A rapid and sensitive method for the quantitation of microgram quantities of protein utilizing the principle of protein-dye binding. Anal Biochem 72:248-254

Colaço A, Dehairs F, Desbruyères D (2002) Nutritional relations of deep-sea hydrothermal fields at the Mid-Atlantic Ridge: a stable isotope approach. Deep-Sea Res I 49:395-412

Fossing H, Gallardo VA, Jørgensen BB, Hüttel M, Nielsen LP, Schulz H, Canfield DE, Forster S, Glud RN, Gundersen JK, Küver J, Ramsing NB, Teske A, Thamdrup B, Ulloa A (1995) Concentration and transport of nitrate by the mat-forming sulphur bacterium Thioploca. Nature 374:713-715

Fricke H, Geire O, Stetter K, Alfredsson GA, Kristjansson JK, Stoffers $P$, Svavarsson J (1989) Hydrothermal vent communities at the shallow subpolar Mid-Atlantic ridge. Mar Biol 102:425-429

Gaill F, Desbruyères D, Prieur D (1987) Bacterial communities associated with "Pompei Worms" from the East Pacific Rise hydrothermal vents: SEM, TEM observations. Microb Ecol 13:129-139

Jacq E, Prieur D, Nichols P, White DC, Porter T, Geesey GG (1989) Microscopic examination and fatty acid characterization of filamentous bacteria colonizing substrata around subtidal hydrothermal vents. Arch Microbiol 152:64-71

Jannasch HW (1985) The chemosynthetic support of life and the microbial diversity at deep-sea hydrothermal vents. Proc Roy Soc Lond B 225:227-297

Jannasch HW, Nelson DC, Wirsen CO (1989) Massive natural occurrence of unusually large bacteria (Beggiatoa sp.) at a hydrothermal deep-sea vent site. Nature 342:834-836

Johnson KS, Beehler CL, Sakamoto-Arnold CM, Childress JJ (1986) In situ measurements of chemical distributions in a deep-sea hydrothermal vent field. Science 231:1139-1141

Johnson KS, Childress JJ, Hessler RR, Sakamoto-Arnold CM, Beehler CL (1988) Chemical and biological interactions in the Rose Garden hydrothermal vent field, Galapagos spreading center. Deep-Sea Res 35:1723-1744

Jørgensen BB, Gallardo VA (1999) Thioploca spp.: filamentous sulfur bacteria with nitrate vacuoles. FEMS Microbiol Ecol 28:301-313

Jørgensen BB, Nelson DC (2004) Sulfide oxidation in marine sediments: geochemistry meets microbiology. In: Amend JP, Edwards KJ, Lyons TW (eds) Sulfur biogeochemistry-past and present: geological society of America special paper, vol 379. Geological Society of America, Boulder, pp 63-81

Kalanetra KM, Huston SL, Nelson DC (2004) Novel, attached, sulfuroxidizing bacteria at shallow hydrothermal vents possess vacuoles not involved in respiratory nitrate-accumulation. Appl Environ Microbiol 70:7487-7496

Kalanetra KM, Joye SB, Sunseri NR, Nelson DC (2005) Novel vacuolate sulfur bacteria from the Gulf of Mexico reproduce by reductive division in three dimensions. Environ Microbiol 7:1451-1460 
Maddison DR, Maddison WP (2002) MacClade 4: analysis of phylogeny and character evolution, version 4.05. Sinauer Associates, Sunderland

Maier S, Gallardo VA (1984) Thioploca araucae sp nov. and Thioploca chileae sp. nov. Intl J Syst Bacteriol 34:414-418

Mattison RG, Abbiati M, Dando PR, Fitzsimons MF, Pratt SM, Southward AJ, Southward EC (1998) Chemoautotrophic microbial mats in submarine caves with hydrothermal sulphidic springs at Cape Palinuro, Italy. Microb Ecol 35:58-71

McCollom TM, Shock EL (1997) Geochemical constraints on chemolithoautotrophic metabolism by microorganisms in seafloor hydrothermal systems. Geochim Cosmochim Acta 61:4375-4391

McHatton SC (1998) Ecology and physiology of autotrophic sulfur bacteria from sulfide-rich seeps and marine sediments. Ph.D. Dissertation, University of California, Davis. p 168

McHatton SC, Barry JP, Jannasch HW, Nelson DC (1996) High nitrate concentrations in vacuolate, autotrophic marine Beggiatoa spp. Appl Environ Microbiol 62:954-958

Muyzer G, de Waal EC, Uitterlinden AG (1993) Profiling of complex microbial populations by denaturing gradient gel electrophoresis analysis of polymerase chain reaction-amplified genes coding for 16 s RNA. Appl Environ Micobiol 59:695-700

$\mathrm{Mu} \beta$ mann $\mathrm{M}$, Schulz HN, Strotmann B, Kjær T, Nielsen LP, Rosselló-Mora RA, Amann RI, Jørgensen BB (2003) Phylogeny and distribution of nitrate-storing Beggiatoa spp in coastal marine sediments. Environ Microbiol 5:523-533

Mußmann M, Hu FZ, Richter M, de Beer D, Preisler A, Jørgensen BB, Huntemann M, Glöckner FO, Amann R, Koopman WJH, Lasken RS, Janto B, Hogg J, Stoodley P, Boissy R, Ehrlich GD (2007) Insights into the genome of large sulfur bacteria revealed by analysis of single filament. PLoS Biol 5:e230. doi: 10.1371/journal.pbio.0050230

Nelson DC, Jannasch HW (1983) Chemoautotrophic growth of a marine Beggiaota in sulfide-gradient cultures. Arch Microbiol 136:262-269

Nelson DC, Jørgensen BB, Revsbach NP (1986) Growth pattern and yield of a chemoautotrophic Beggiatoa sp in oxygen-sulfide microgradients. Appl Environ Microbiol 52:225-233

Nelson DC, Wirsen CO, Jannasch HW (1989) Characterization of large, autotrophic Beggiatoa spp abundant at hydrothermal vents of the Guaymas Basin. Appl Environ Microbiol 55:2909-2917

Nelson DC, Hagen KD, Edwards DB (1995) The gill symbiont of a hydrothermal vent mussel, Bathymodiolus thermophilus, is a psychrophilic, chemoautotrophic sulfur bacterium. Mar Biol 121:487-495

Nikolaus R, Ammerman JW, MacDonald IR (2003) Distinct pigmentation and trophic modes in Beggiatoa from hydrocarbon seeps in the Gulf of Mexico. Aq Microb Ecol 32:85-93

Otte S, Kuenen JG, Nielsen LP, Paerl HW, Zopfi J, Schulz HN, Teske A, Strotmann B, Gallardo VA, Jørgensen VA (1999) Nitrogen, carbon and sulphur metabolism in natural Thioploca samples. Appl Environ Microbiol 65:3148-3157

Pitcher DG, Saunders NA, Owen RJ (1989) Rapid extraction of bacterial genomic DNA with guanidium thiocyanate. Lett Appl Microbiol 8:151-156

Polz MF, Robinson JJ, Cavanaugh CM (1998) Trophic ecology of massive shrimp aggregations at a Mid-Atlantic Ridge hydrothermal vent site. Limnol Oceanogr 43:1631-1638

Sayama M (2001) Presence of nitrate-accumulating sulfur bacteria and their influence on nitrogen cycling in a shallow coastal marine sediment. Appl Environ Microbiol 67:3481-3487

Schulz HN, de Beer D (2002) Uptake rates of oxygen and sulfide measured with individual Thiomargarita namibiensis cells by using microelectrodes. Appl Environ Microbiol 68:5746-5749

Schulz HN, Brinkhoff T, Ferdelman TG, Hernández Mariné M, Teske A, Jørgensen BB (1999) Dense populations of a giant sulfur bacterium in Namibian shelf sediments. Science 284:493-495

Stein J (1984) Subtidal gastropods consume sulfur-oxidizing bacteria: evidence from coastal hydrothermal vents. Science 223:696-698

Swofford DL (2000) PAUP*. Phylogenetic analysis using parsimony (*and other methods), version 4. Sinauer Associates, Sunderland

Urcuyo IA, Massoth GJ, Julian D, Fisher CR (2003) Habitat, growth and physiological ecology of a basaltic community of Ridgeia piscesae from the Juan de Fuca Ridge. Deep-Sea Res IOceanogr Res Papers 50:763-780

Urcuyo IA, Bergquist DC, MacDonald IR, VanHorn M, Fisher CR (2007) Growth and longevity of the tubeworm Ridgeia piscesae in the variable diffuse flow habitats of the Juan de Fuca Ridge. Mar Ecol Prog Ser 344:143-157

Van Dover CL (2000) The ecology of deep-sea hydrothermal vents. Princeton University Press, Princeton

Van Dover CL, Fry B (1994) Microorganisms as food resources at deep-sea hydrothermal vents. Limnol Oceanogr 39:51-57

Weisburg WG, Barns SM, Pelletier DA, Lane DJ (1991) 16S ribosomal DNA amplification for phylogenetic study. J Bacteriol 173:697-703 